\title{
Patterns of microhabitat utilization by mobile megafauna on the southern New England (USA) continental shelf and slope
}

\author{
Peter J. Auster ${ }^{1, *}$, Richard J. Malatesta ${ }^{2}$, Susan C. LaRosa ${ }^{1}$ \\ ${ }^{1}$ NOAA National Undersea Research Center, The University of Connecticut at Avery Point, Groton, Connecticut 06340, USA \\ ${ }^{2}$ Sea Education Association, PO Box 6, Woods Hole, Massachusetts 02543, USA
}

\begin{abstract}
Video transects from occupied submersibles were used to define associations of mobile megafauna (primarily demersal fishes and crustaceans) with microhabitat features including shell, burrow, biogenic depression, biogenic depression with adjacent burrow, sand wave crest, boulder, and burrowed clay outcrop. Sites were located on low-relief bottoms across the southern New England (USA) continental shelf and slope at depths of 55,240 , and $712 \mathrm{~m}$. No significant diel differences in abundance were found for the 8 taxa censused at the $55 \mathrm{~m}$ (inner shelf) site. Non-random distributions and associations with specific microhabitats were found for the 8 taxa from diumal transects and 6 taxa had non-random distributions from nocturnal transects. Silver hake Merluccius bilinearis and little skate Raja erinacea were associated with particular microhabitats during the day but were randomly distributed at night. These shifts in pattern are attributed to diel differences in feeding behavior. Three of 6 taxa at a $240 \mathrm{~m}$ (outer shelf) site and 5 of 6 taxa at a $712 \mathrm{~m}$ (slope) site showed non-random distributions and associations with specific microhabitats from diurnal transects. Observations with an ROV (remotely operated vehicle) at inner shelf sites $(33$ to $55 \mathrm{~m}$ ) identified a distinction between species which produce biogenic depressions and species which later occupy abandoned depressions. We posit that associations with microhabitat features enhance individual fitness possibly by reducing contact with potential predators and enhancing the ability to capture prey. Use of microhabitat features occurs in assemblages where predators of focal organisms are abundant and possibly where prey density allows ambush predator tactics.
\end{abstract}

KEY WORDS: Submersible $\cdot$ ROV $\cdot$ Transect $\cdot$ Predator avoidance Prey capture

\section{INTRODUCTION}

Habitat has been defined as 'the structural component of the environment that attracts organisms and serves as a center of biological activity' (Peters \& Cross 1992). The environmental characteristics which define the habitats of megafaunal organisms, fishes and crustaceans in particular, can be found at a variety of spatial and temporal scales (Langton et al. 1995). At the regional scale, Murawski (1993) found that seasonal and annual variations in seawater temperature explained the annual variation in the distribution for 17 of 36 species of fish and squid on the northeast United

\footnotetext{
•E-mail: auster@uconnvm.uconn.edu
}

States continental shelf and slope. Within this region, temporally stable associations of species have been found and tend to follow isotherms and isobaths (Colvocoresses \& Musick 1984, Overholtz \& Tyler 1985, Phoel 1986, Gabriel 1992). Nearshore and midshelf species were primarily influenced by variations in temperature while outer-shelf and slope species were more affected by depth. Species groups were seasonal and often split or showed changes in composition that correlated with temperature patterns. In the Middle Atlantic Bight, no mesoscale correlations with sediment type have been found (Colvocoresses \& Musick 1984, Phoel 1986).

Nested within regional scale patterns, small-scale variations in abundance and distribution can be partially attributed to variation in topographic structure. 
Wigley \& Theroux (1970) recognized that the microtopography at photographic stations on Georges Bank (NW Atlantic) was greatly influenced by the feeding and shelterseeking activities of demersal fishes. Other studies (Wigley \& Theroux 1971, Uzmann et al. 1978, Valentine et. al. 1980) have described relationships of fishes and crustaceans with certain microtopographic (= microhabitat) features (e.g. depressions, burrows, sessile fauna) but these observations were generally ancillary components of other studies. Cooper \& Uzmann (1980) developed a general classification scheme of habitat types and associated fauna for northeast U.S. continental shelf, slope and submarine canyon habitats. This scheme was based on direct observation of faunal-habitat relationships and provided a framework to determine changes in the density of organisms between habitat types (e.g. Cooper et al. 1987). Subsequent studies of low topography continental shelf habitats have shown statistically significant associations of megafaunal species with specific microhabitat features (Auster et al. 1991, 1994, Malatesta et al. 1992).

Our ultimate goal is to discem the role that physical habitat plays in the dynamic aspects of distribution and abundance of mobile species in temperate and boreal marine systems. In particular, we wish to determine if associations with particular habitat features increase the fitness of individuals. While studies have been conducted which focus on the ecological role of particular species associations with particular habitat features, little work has been done which discerns the pattern and frequency of use of habitat features by assemblages of megafaunal species (but see Able et al. 1982, Grimes et al. 1986, Cooper et al. 1988, Felley \& Vecchione 1995). Herein we describe associations of mobile fauna with particular microhabitats at a series of stations across the continental shelf and slope of the Middle Atlantic Bight. The present question is: Are associations of mobile fauna with various microhabitats a common behavioral attribute of species in cold temperate marine assemblages?

\section{METHODS}

Video transects were conducted at a series of stations across the Middle Atlantic Bight at 55, 240, and $712 \mathrm{~m}$ sites using DSVs 'Delta' and 'NR-1' (Fig 1). The

Table 1. Summary of dive locations off of southern New England, USA

\begin{tabular}{|clccc|}
\hline Year & $\begin{array}{l}\text { Dive } \\
\text { system }\end{array}$ & $\begin{array}{c}\text { Depth } \\
(\mathrm{m})\end{array}$ & $\begin{array}{c}\text { Temp. } \\
\left.{ }^{\circ} \mathrm{C}\right)\end{array}$ & Location \\
\hline 1989 & 'Delta' & 55 & 11.6 & $40^{\circ} 50.3^{\prime} \mathrm{N}, 70^{\circ} 55.6^{\prime} \mathrm{W}$ \\
1990 & 'NR-1' & 712 & $4.3-5.1$ & $39^{\circ} 54.0^{\prime} \mathrm{N}, 71^{\circ} 00.0^{\prime} \mathrm{W}$ \\
1991 & 'Delta' & 240 & $10.3-11.4$ & $40^{\circ} 00.5^{\prime} \mathrm{N}, 71^{\circ} 19.3^{\prime} \mathrm{W}$ \\
& 'NURP 1' & $33-55$ & 10.4 & $41^{\circ} 00.8^{\prime} \mathrm{N}, 71^{\circ} 32.6^{\prime} \mathrm{W}$ \\
& & 14.9 & $41^{\circ} 12.7^{\prime} \mathrm{N}, 71^{\circ} 37.9^{\prime} \mathrm{W}$ \\
& & 11.4 & $40^{\circ} 50.3^{\prime} \mathrm{N}, 70^{\circ} 55.6^{\prime} \mathrm{W}$ \\
\hline
\end{tabular}


site and the field of view was $2.50 \mathrm{~m}^{2}$. This camera was calibrated using vehicle speed to determine the distance an object traveled across the field of view. Speed was determined using a doppler speed log mounted on the hull of the submersible. Substrate type varied between the 55, 240, and $712 \mathrm{~m}$ sites and was previously classified as sand and shell, silty-sand, and silt respectively (Wigley \& Theroux 1981, Auster et al. 1991).

Triplicate transects were conducted at the $55 \mathrm{~m}$ site both day and night to assess diel variation in the abundance of mobile fauna and microhabitat use. To determine if there were diel differences in abundance, individual transects were treated as strips and abundances standardized to number per hectare. Video path width was $0.53 \mathrm{~m}$ and distance along the transect was determined using Loran-C coordinates (range 0.65 to $0.97 \mathrm{~km}$ ). A Mann-Whitney $U$ test was used to determine significant differences in abundance for individual taxa. Single transects were conducted at the other 2 sites to determine patterns in microhabitat use only. Transect lengths were $1.8 \mathrm{~km}$ at the $240 \mathrm{~m}$ site and $23.2 \mathrm{~km}$ at the $712 \mathrm{~m}$ site.

The data extracted from all video transects to determine patterns in microhabitat use included species-microhabitat associations as well as the relative abundance of each microhabitat resource. Associations were attributed to individuals if they were within 1 body length of a microhabitat feature. Otherwise the individual was associated with the background habitat (e.g. flat sand-silt). The relative frequency of microhabitats was determined for the 55 and $240 \mathrm{~m}$ sites by stopping the video tape at $60 \mathrm{~s}$ intervals along the transect and attributing the feature in the field of view to a microhabitat category. A different method was used to determine the relative frequency of microhabitats from the $712 \mathrm{~m}$ transect because multiple features were seen in single video frames. The tape was stopped at $120 \mathrm{~s}$ intervals and an acetate overlay with 10 randomly marked dots was overlaid on the video image. The microhabitat feature under each dot was assigned to a particular microhabitat type. A chi-square test of homogeneity of distribution, with expected frequencies weighted by the percent frequency of occurrence of each microhabitat, was used to determine if distributions of taxa were non-random. The percent difference between observed and expected values from the chi-square computation was used as a measure of association of a taxon with a particular microhabitat.

A list of taxa observed during all dives is presented in Table 2. Names of fishes follow Robins et al. (1991) and of crustaceans follow Austin et al. (1989).
Table 2. Species observed at each location across the continental shelf and slope. Common names are listed and used throughout the text

\begin{tabular}{ll|} 
Inner sheli & \\
Cancer irroratus & Atlantic rock crab \\
Homarus americanus & American lobster \\
Loligo pealei & Longfinned squid \\
Macrozoarces americana & Ocean pout \\
Merluccius bilinearis & Silver hake \\
Myoxocephalus octodecemspinosus & Longhorn sculpin \\
Pagurus spp. & Hermit crab \\
Peprilus tricanthus & Butterfish \\
Pleuronectiformes & Flounder \\
Pomatomus saltatrix & Bluefish \\
Raja erinacea & Little skate \\
Stenotomus chrysops & Scup \\
Urophycis chuss & Red hake \\
& \\
Outer shelf & \\
Cancer borealis & \\
Conger oceanicus (?) & Jonah crab \\
Helicolenus dactylopterus & Conger eel \\
Pleuronectiformes & Blackbellied rosefish \\
Urophycis tenuis & Flounder \\
Slope & White hake \\
Geryon quinquedens & \\
Coryphaenoides rupestris and & Grenadier \\
Nezumia bairdii & Witch flounder \\
Glyptocephalus cynoglossus & Galatheid crab \\
Munida spp. & Northern cutthroat eel \\
Synaphobranchus kaupi & Longfinned hake \\
Urophycis chesteri & \\
& \\
\hline & \\
\hline
\end{tabular}

\section{RESULTS}

\section{5 m site}

Microhabitats included biogenic depressions, sand wave crests, and surficial shell produced by the ocean quahog Arctica islandica. No significant diel differences in abundance were found for any of the 8 taxa censused (Table 3). Non-random distributions and associations with specific microhabitats (Fig. 2) were found for all 8 taxa from diurnal transects and 6 taxa from nocturnal transects (Table 4 ). While silver hake and little skate were associated with particular microhabitat features during the day, they were randomly distributed at night. Ocean pout, longhorn sculpin, and Atlantic rock crab used shell and biogenic depressions both day and night. Red hake used both types of microhabitats more than expected during the day but used shell less than expected at night. Flounders used biogenic depressions more than expected both day and night. Individuals using shell were observed both within the interstices of shell aggregates or simply in direct contact with the shell surface. Silver hake, as well as hermit crabs, used both the peaks of sand waves and biogenic depressions more than expected. 
Table 3. Standardized abundance (corrected for length of transect ${ }_{i}$ presented as no. ha ${ }^{-1}$ ) of taxa from individual transects at the $55 \mathrm{~m}$ site. Transects 1 to 3 were made dunng daylight hours and Transects 4 to 6 at night. Differences between abundance estimates were made using a Mann-Whitney $U$-test (significant at $\mathrm{p}<0.05$ ); ns: not significant

\begin{tabular}{|c|c|c|c|c|c|c|c|}
\hline \multirow[t]{2}{*}{ Taxon } & \multicolumn{6}{|c|}{ Standardized abundance per transect } & \multirow{2}{*}{$\begin{array}{l}\text { Day-night } \\
\text { comparison }\end{array}$} \\
\hline & 1 & 2 & 3 & 4 & 5 & 6 & \\
\hline Ocean pout & 1732.0 & 1141.0 & 1455.4 & 1109.4 & 430.2 & 902.5 & ns \\
\hline Little skate & 305.7 & 142.6 & 291.1 & 701.8 & 543.4 & 494.9 & ns \\
\hline Red hake & 152.8 & 326.0 & 271.7 & 226.4 & 90.6 & 349.3 & ns \\
\hline Silver hake & 789.6 & 550.1 & 2309.3 & 611.3 & 67.9 & 349.3 & ns \\
\hline Longhorn sculpin & 713.2 & 489.0 & 116.4 & 588.6 & 407.5 & 669.6 & ns \\
\hline Pleuronectiformes & 738.7 & 305.6 & 349.3 & 339.6 & 22.6 & 203.8 & ns \\
\hline Atlantic rock crab & 738.7 & 366.7 & 213.5 & 543.4 & 339.6 & 291.1 & ns \\
\hline Hermit crab & 3285.8 & 998.4 & 4308.2 & 2037.6 & 679.2 & 3318.8 & ns \\
\hline
\end{tabular}
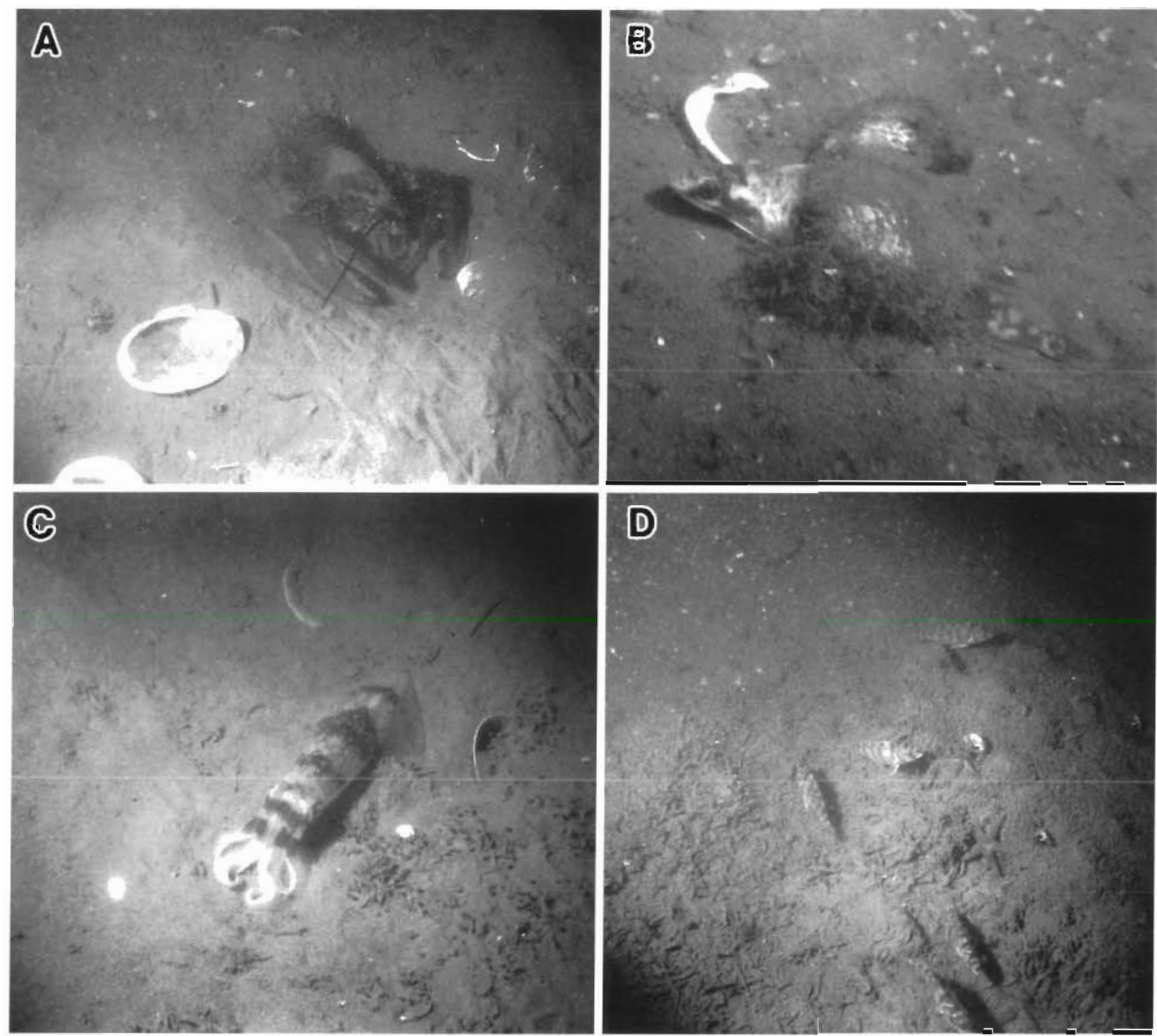

Fig. 2. Inner shelf sites of of southern New England, USA. (A) American lobster in a biogenic depression, (B) red hake between ocean quahog valves, (C) longfinned squid in a biogenic depression at night., (D) juvenile scup in a depression probably formed by a skate 
Table 4. Percent difference between observed and expected values (from chi-square test) of abundance of individual taxa associated with each microhabitat type from day and night transects at the $55 \mathrm{~m}$ site, southern New England continental shelf. Expected abundances for day and night transects were weighted based on the percent of each microhabitat type observed in Transects $1-3$ and 4-6, respectively. Chi-square tests of homogeneity of distribution of abundance were computed for each taxon for diurnal and nocturnal transects (significance levels are $\cdots p<0.05, \cdot p<0.010,{ }^{n} p>0.10$ ). Microhabitat distributions for diurnal transects $(n=367)$ : tlat sand $46.32 \%$, shell $35.42 \%$, sand wave crest $16.08 \%$, biogenic depression $2.18 \%$. Microhabitat distributions for nocturnal transects $(\mathrm{n}=322)$ : flat sand $56.52 \%$, shell $32.30 \%$, sand wave crest $9.94 \%$, biogenic depression $1.24 \%$

\begin{tabular}{|c|c|c|c|c|c|}
\hline \multirow{2}{*}{ Taxon } & \multicolumn{4}{|c|}{ Microhabitat type } & \multirow{2}{*}{ Chi-square } \\
\hline & $\begin{array}{l}\text { Flat } \\
\text { sand }\end{array}$ & Shell & $\begin{array}{c}\text { Sand wave } \\
\text { crest }\end{array}$ & $\begin{array}{c}\text { Biogenic } \\
\text { depression }\end{array}$ & \\
\hline \multirow{2}{*}{$\begin{array}{r}\text { Ocean pout (day) } \\
\text { (night) }\end{array}$} & -60 & 87 & -69 & 302 & $\cdots$ \\
\hline & -82 & 138 & -80 & 794 & .. \\
\hline \multirow[t]{2}{*}{ Little skate } & 17 & -35 & -35 & 471 & .. \\
\hline & 3 & -5 & -2 & 12 & ns \\
\hline \multirow[t]{2}{*}{ Red hake } & -67 & 96 & -32 & 100 & . \\
\hline & 2 & -52 & -61 & 1775 & .. \\
\hline \multirow[t]{2}{*}{ Silver hake } & 12 & -29 & 15 & 100 & .. \\
\hline & 14 & -34 & 20 & 92 & ns \\
\hline \multirow[t]{2}{*}{ Longhorn sculpin } & -81 & 111 & -53 & 311 & .. \\
\hline & -68 & 94 & -85 & 1346 & . \\
\hline \multirow[t]{2}{*}{ Pleuronectiformes } & 6 & -51 & -10 & 766 & . \\
\hline & -31 & -60 & -13 & 3003 & $\because$ \\
\hline \multirow[t]{2}{*}{ Atlantic rock crab } & -30 & 61 & -71 & 182 & .. \\
\hline & -42 & 90 & -100 & 392 & .. \\
\hline \multirow[t]{2}{*}{ Hermit crab } & -7 & -13 & 38 & 89 & $\cdots$ \\
\hline & 1 & -52 & 106 & 451 & .. \\
\hline
\end{tabular}

\section{0 m site}

Microhabitats included biogenic depressions and burrows. Four of 5 taxa were non-randomly distributed and associated with specific microhabitats (Table 5). White hake, blackbellied rosefish and flounders used biogenic depressions more than expected while conger eels used burrows more than expected. Jonah crabs were randomly distributed throughout the transect.

\section{$712 \mathrm{~m}$ site}

Microhabitats included biogenic depressions, burrows, biogenic depressions with adjacent burrows, and boulders (Fig. 3A, B). Five of 6 taxa were nonrandomly distributed and associated with specific microhabitats (Table 6). Witch flounder used depressions more than expected. Northern cutthroat eel and longfinned hake used boulders more than expected. Longfinned hake were associated with biogenic depressions, burrows, and biogenic depressions with adjacent burrows. Galatheid crabs used burrows and biogenic depressions with adjacent burrows more than expected. Red crabs were randomly distributed throughout the transect. Areas of clay outcrops were

Behavioral observations during ROV dives, made near dusk and at night, at this and other nearby sites demonstrated that some species produced depression features and others used vacated depressions. For example, juvenile scup and squid were observed in biogenic depressions of variable size (number of observations $=5$ ). The largest, approximately $40 \mathrm{~cm}$ across, was apparently produced by a skate (due to the distinctive outline). Smaller depressions generally were occupied by smaller individuals of both scup and squid. These smaller depressions were likely produced by other fishes (e.g. red hake, ocean pout, flounders) and crustaceans (e.g. Atlantic rock crab, American lobster) which excavated the bottom for shelter and prey. Four butterfish were observed singly at the bottom over flat sand, shell, and in a biogenic depression. On one occasion, a butterfish occupied a biogenic depression momentarily before being chased out by a bluefish.
Table 5. Percent difference between observed and expected values (from chi-square test) of abundance of individual taxa associated with each microhabitat type at the $240 \mathrm{~m}$ site, southern New England continental shelf Expected abundances were based on the measured distribution of microhabitat types. A chi-square test of homogeneity of distribution of abundance was computed for each taxon (significant at $\cdots p<0.05, " p<0.10$, $\left.{ }^{{ }^{n}} \mathrm{p}>0.10\right)$. Microhabitat distributions $(\mathrm{n}=1161)$ : flat sand $83.12 \%$, biogenic depression $12.06 \%$, burrow $4.82 \%$

\begin{tabular}{|lcccc|}
\hline Taxon & \multicolumn{3}{c|}{$\begin{array}{c}\text { Microhabitat type } \\
\text { Flat } \\
\text { silty-sand }\end{array}$} & Chi-squarenic \\
depression & Burrow & \\
\hline White hake & -2 & 54 & -100 &. \\
Blackbellied rosefish & -83 & 611 & -100 &. \\
Conger eel & -16 & -17 & 312 & $\ldots$ \\
Pleuronectiformes & -33 & 257 & -78 &. \\
Jonah crab & -10 & 107 & -100 & ns \\
\hline
\end{tabular}



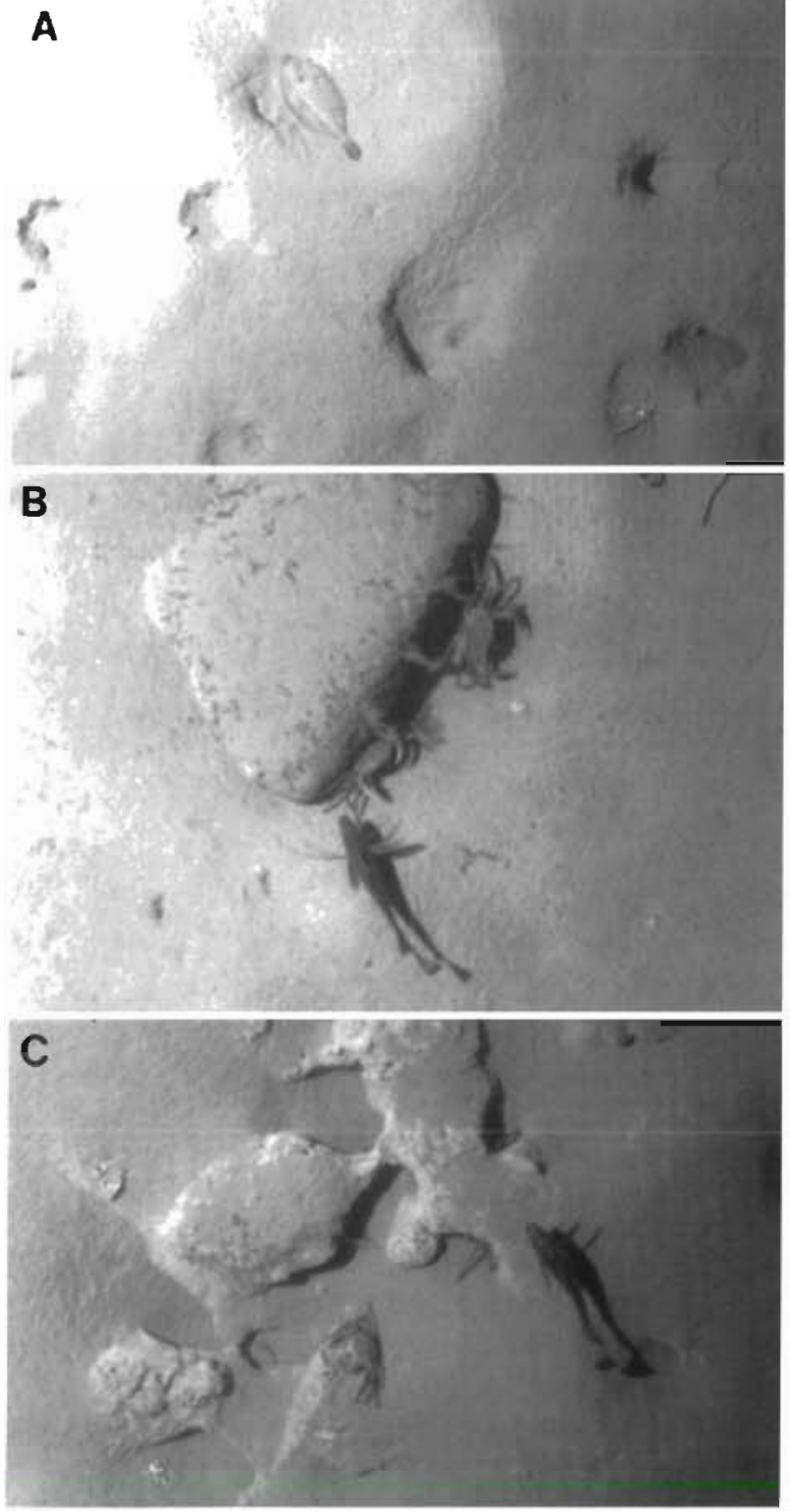

Fig. 3. Slope site off of southern New England, USA. (A) Witch flounder in a biogenic depression and galatheid crab at a burrow entrance adjacent to a depression. (B) longfinned hake and red crabs along the edge of a glacial erratic boulder, (C) red crabs and longfinned hake in exposed clay burrows

\section{DISCUSSION}

The use of microhabitat features is a common behavioral attribute of fishes and crustaceans across the continental shelf and upper slope. While patterns of species composition and distribution have been discerned for regional fish assemblages (Colvocoresses \& Musick 1984, Overholtz \& Tyler 1985, Phoel 1986, Gabriel 1992), small-scale habitat structure contributes to variation in distribution within assemblage types. The use of microhabitats by fishes and crustaceans is apparently facultative, as individuals of most taxa use a variety of microhabitats or were observed to be associated with the background habitat type

Diel transects at the $55 \mathrm{~m}$ inner shelf site indicated silver hake and little skate exhibited diel shifts from use of specific microhabitats during the day to distributions independent of microhabitat type during the night. Silver hake are known to move off the bottom at night to feed (Bowman \& Bowman 1980) and, although there was no significant difference in abundance between day and night, feeding behavior may cause shifts in distribution relative to microhabitats. Skates are also known to remain buried in depressions during the day and are more active at night, probably due to diel differences in foraging (Michalopoulos 1990).

The role that use of microhabitats plays in increasing individual fitness may include predator avoidance and prey capture. Individuals occupying various microhabitat features have been observed to retreat into the

Table 6. Percent difference between obscrved and expected values (from chi-square test) of abundance of individual taxa associated with each microhabitat type at the $712 \mathrm{~m}$ site, southern New England continental slope. Expected abundances were based on the measured distribution of microhabitat types. A chi-square test of homogeneity of distribution of abundance was computed for edch taxon (significant at ${ }^{\prime} p<0.05,{ }^{\circ} p<0.10,{ }^{n k} p>0.10$ ). Microhabitat distributions ( $n=2170$ ): flat silt-clay $80.98 \%$, biogenic depression $16.35 \%$, burrow $1.11 \%$, biogenic depression with adjacent burrow $1.52 \%$, boulder $0.04 \%$

\begin{tabular}{|c|c|c|c|c|c|c|}
\hline \multirow[t]{2}{*}{ Taxa } & \multicolumn{5}{|c|}{ Microhabitat type } & \multirow[t]{2}{*}{ Chi-square } \\
\hline & $\begin{array}{l}\text { Flat } \\
\text { silt }\end{array}$ & $\begin{array}{l}\text { Biogenic } \\
\text { depression }\end{array}$ & Burrow & $\begin{array}{c}\text { Biogenic } \\
\text { depression/burrow }\end{array}$ & Bouider & \\
\hline Witch flounder & -37 & 202 & -100 & -100 & -100 & . \\
\hline Northern cutthroat ee! & 16 & -85 & -87 & 93 & 598 & .. \\
\hline Longfinned hake & -34 & 97 & 61 & 604 & 4364 & .. \\
\hline Grenadier & 2 & -32 & -100 & 339 & -100 & . \\
\hline Red crab & 1 & -13 & 33 & 62 & -100 & ns \\
\hline Galatheid crab & -72 & 49 & 3224 & 996 & -100 & .. \\
\hline
\end{tabular}


interstices of the shell, among valves on the sediment surface, into depressions in the sediment surface, and into burrows. Laboratory studies have confirmed that the use of microhabitat features can play a functional role in enhancing survivorship. In the presence of a predator, juvenile cod Gadus morhua survivorship was enhanced by a shift in substrate preference from sand or gravel-pebble to cobble (Gotceitas \& Brown 1993). Individuals used the interstices of the cobble substrate as a refuge. This work illustrated that even relatively subtle changes in habitat complexity can have an effect on predation pattern. Increased habitat complexity has also been shown to increase survivorship of early ontogenetic stages of the American lobster (Wahle 1992a, b, Wahle \& Steneck 1992). Use of microhabitats may also play a role in ambush predation tactics by providing a focal site in which the predator may not be recognized by the prey. For example, use of sand wave crest peaks may be a preferred site for ambushing drifting demersal zooplankton and small fishes by silver hake. We have observed other predators using microhabitats as sites for ambush predator tactics as well (i.e. red hake, ocean pout, longhorn sculpin, squid, conger eel, and blackbellied rosefish; unpubl. obs.). Whether for predator avoidance or prey capture, microtopographic features may serve to block visual and acoustic (i.e. proprioceptive) recognition of occupants.

The use of microhabitats, such as biogenic depressions, produced by another species may be a common part of the behavioral repertoire of taxa such as squid, scup, and butterfish. Species which seek refuge from predators during specific periods of the day (e.g. nocturnal, crepuscular), or require particular sites to optimize ambush predation tactics, may not have the behavioral plasticity or morphological attributes to produce their own depression features. This linkage between taxa may influence survivorship rates of cohorts of microhabitat users when population sizes of microhabitat producers are greatly reduced.

The availability of microhabitat resources is dynamic in nature. Sedimentary features such as depressions and burrows can fill in or collapse and shell can become resorted, buried or exposed. At our $55 \mathrm{~m}$ station, the coverage of shell has varied from 1987 to 1993 with expansions and contractions in area covered. Eroded sand wave features, observed during the summer at this site, suggest storm events mediate burial and exposure. Ocean quahog shell deployed on the bottom for an experiment south of Block Island (Rhode Island, USA) in $47 \mathrm{~m}$ depth was found buried under several $\mathrm{cm}$ of sediment after a hurricane passed through the region in 1991 Larval blue mussels Mytilus edulis attach to hard rock substrates, small pieces of shell, and to each other to produce extensive 'mats' over sand and mud to depths exceeding $33 \mathrm{~m}$ in eastern Long Island Sound (New York, USA). Crustaceans and fishes utilize these mats in a variety of ways, such as for prey, shelter from predators (by burrowing within or under the mat), as well as for sites to reduce energy used for station keeping in strong currents (along edges of the mat). As the mussel population declines through predation and senescence, mussel shell becomes the dominant habitat feature. Large 'windrows' of shell were observed at 4 to $8 \mathrm{~m}$ intervals at $20 \mathrm{~m}$ depth using an ROV in eastern Long Island Sound during the fall of 1992. The orientation of windrows was north-south, indicating that east-west currents and possibly storm-generated surges interacted to create these features. Juvenile fishes and crustaceans (i.e. scup, American lobster, Atlantic rock crab, Jonah crab, and longfinned squid) were associated with these features. Side-scan sonar surveys and observations with an ROV during spring and summer 1993 showed that windrows were no longer present and the associated organisms were either absent or at lower densities than during the previous survey. It is tempting to speculate that availability of microhabitats from year to year may affect year class strength, or at least that of a specific cohort, since juvenile life stages would utilize these resources for shelter and consequently reduce predator-induced mortality

While we have shown that use of microhabitats is a common behavioral attribute of fishes and crustaceans in low topography habitats on the continental shelf and upper slope off southern New England, we must ask: How universal are associations with such features by megafaunal species? If use of microhabitat features is mediated by predator and prey densities (i.e. based on predator avoidance and prey capture) then individuals may utilize features based on predation risk and hunger level (Sale 1991, Walters \& Juanes 1993). The fish assemblage on the northeast U.S. continental shelf is a predator-dominated system (Sissenwine 1984, Sissenwine et al. 1984) Continental shelf and slope regions support predator and prey densities sufficient to elicit such shelter seeking behavior but the density of deep-sea fishes declines with depth (Sulak 1982). A dive to a $2836 \mathrm{~m}$ deep-sea site south of our study area $\left(39^{\circ} 00.0^{\prime} \mathrm{N}, 71^{\circ} 00.0^{\prime} \mathrm{W}\right.$ ) during June 1992 revealed fishes to be widely dispersed and none were associated with any particular microhabitats, although depressions and macroalgal falls were observed (Fig. 4). Antimora rostrata, Coryphaenoides spp., and Halosauropsis macrochir were observed during this dive exhibiting scan and pick foraging behavior. Video of the debris field of the HMS 'Titanic' site $\left(41^{\circ} 43.8^{\prime} \mathrm{N}\right.$, $49^{\circ} 56.8^{\prime} \mathrm{W}$ ), taken during July 1991 at $3775 \mathrm{~m}$, provided experimental evidence of the effect of habitat enhancement on deep-sea fishes. The video showed 


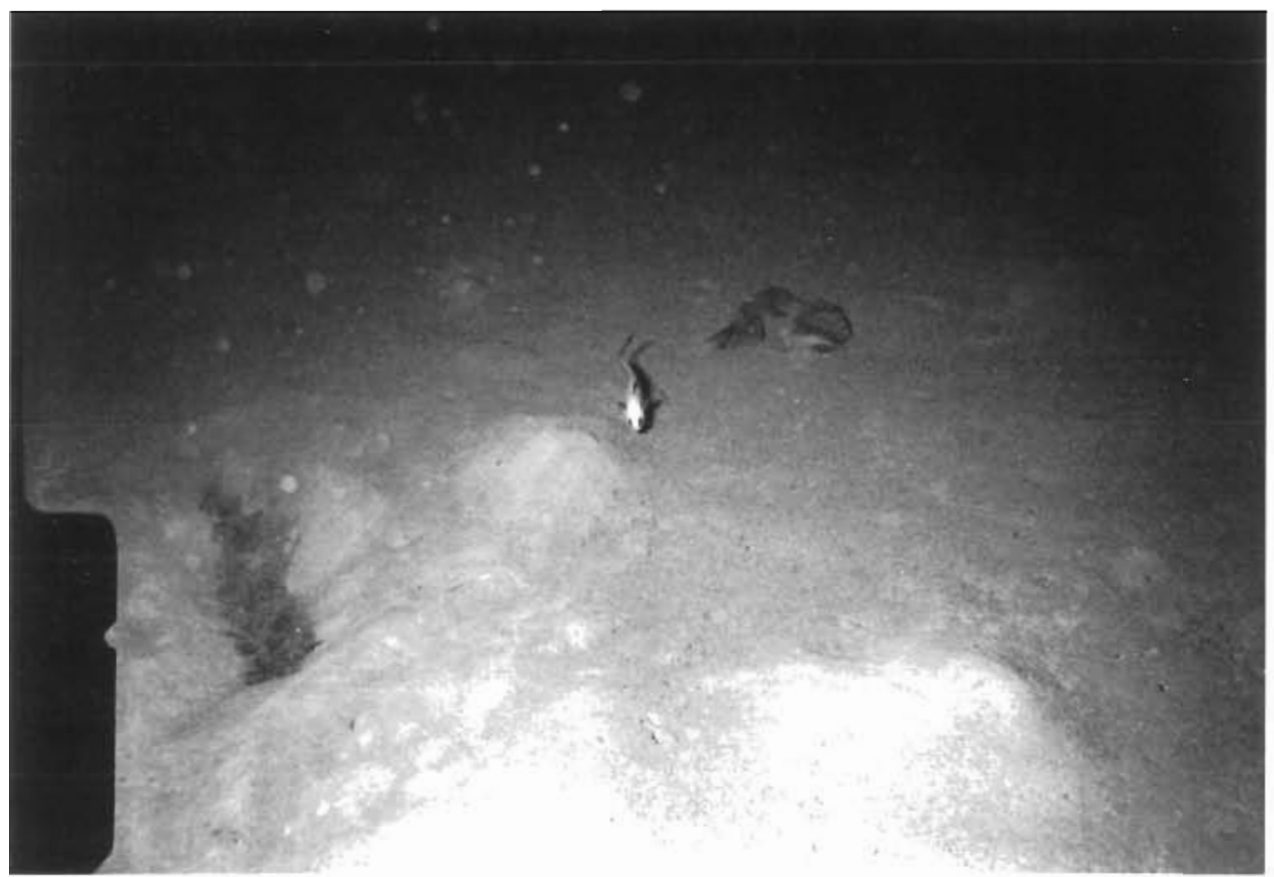

Fig. 4. A Coryphaenoides sp. swimming over the bottom at a 2836 m deep-sea site south of the study area. Note the depression with macroalgal debris

that while munid crabs were occasionally observed burrowed under debris, no fishes were observed using any features for shelter. Only 1 grenadier was observed swimming over the site. These observations indicate that deep-sea fishes do not seek shelter from predators and the density of prey is too low to elicit ambush predator tactics. Sulak (1982) showed that the demersal deep-sea fish fauna in the Middle Atlantic Bight, a eutrophic region of the Atlantic, exhibit 'energetically expensive' life histories (e.g. active foraging). Hence the deep-sea fish fauna of the Middle Atlantic region may not benefit from the use of microhabitat resources.

The role of small-scale habitat features has been central to understanding mechanisms which contribute to variation in populations of coral reef and rock reef fish assemblages (e.g. Sale 1991, Walters \& Juanes 1993). The patterns of distributions observed in this study extend these findings to the enhancement of 'fitness' of several species of demersal fish and crustaceans displaying small-scale habitat behavior responses on the continental shelf and slope of southern New England.

Acknowledgements. We thank the captains and crews of the support ships RV 'J. W. Powell', RV 'Suncoaster', USN 'Sunbird', and RV 'Atlantis II', and the pilots and crews of the submersibles 'Delta', 'NR-1', 'Alvin', and the NURP 1' ROV. Emory Kristof of the National Geographic Society kindly provided the tape of the debris field from 'Mir' submersible dives at the HMS 'Titanic' site. Cynthia Richmond, Anita Jaap. Michael Brace, Christos Michalopoulos, and Gary Grenier assisted dunng the course of this study. The com- ments of 3 anonymous reviewers greatly improved the manuscript. This work was funded by NOAA's National Undersea Research Center at The University of Connecticut (NOAA Grant NA90AA-D-UR128), NOAA's National Undersea Research Program in Silver Spring, Maryland, The Research Foundation of The University of Conneclicut, and The Max and Victoria Dreyfus Foundation. The views expressed herein are those of the authors and do not necessarily reflect the vews of NOAA or any of its sub-agencies.

\section{LITERATURE CITED}

Able KW, Grimes CB, Cooper RA, Uzmann JR (1982) Burrow construction and behavior of tilefish, Lopholatilus chamaeleonticeps, in Hudson submarine canyon. Envir Biol Fish 7:199-205

Auster PJ, Malatesta RJ, Donaldson CLS (1994) Small-scale habitat variability and the distribution of postlarval silver hake, Merluccius bilinearis. In: Gulf of Maine Habitat: Workshop Proceedings. UNH-ME Sea Grant Tech Rep UNHMP-T/DR-SG-94-18. Univ of Maine Sea Grant, Orono, p $82-86$

Auster PJ, Malatesta RJ, LaRosa SC, Cooper RA, Stewart LL (1991) Microhabitat utilization by the megafaunal assemblage at a low relief outer continental shelf site Middle Atlantic Bight, USA. J Northw Atl Fush Sci 11: $59-69$

Austin AB, Abele LG, Felder DL, Hobbs HH Jr, Nanning RB, McLaughlin PA, Farfante LP (1989) Common and scientific names of aquatic invertebrates from the United States and Canada: decapod crustaceans. Am Fish Soc Spec Publ 17

Bowman RE, Bowman EW (1980) Diurnal variation in the feeding and catchability of silver hake (Merluccius bilinear15). Can J Fish Aquat Sc1 37:1565-1572

Colvocoresses JA, Musick JA (1984) Species associations and community composition of Middle Atlantic Bight continental shelf demersal fishes. Fish Bull US 82:295-313

Cooper RA, Shepard AN, Valentune P, Uzmann JR. Hulbert A 
(1987) Pre and post drilling bench marks and monitoring data of ocean floor fauna, habitats, and contaminant loads on Georges Bank and its submarine canyons. Symposia Sories for Undersea Research, Vol 2, Part 2. NOAA, Office of Undersea Research, Rockville, MD, p 17-48

Cooper RA, Uzmann JR (1980) Ecology of juvenile and adult American, Homarus americanus, and European, Homarus gammarus, lobsters. In: Cobb SJ, Phillips BF (eds) Biology of lobsters. Academic Press, New York, p 97-141

Cooper RA, Valentine P, Uzmann JR, Slater RA (1988). Submarine canyons. In: Backus RH, Bourne DW (eds) Georges Bank. Massachusetts Institute of Technology Press, Cambridge, p 52-63

Felley JD, Vecchione M (1995) Assessing habitat use by nekton on the continental slope using archived videotapes from submersibles. Fish Bull US 93:262-273

Gabriel WL (1992) Persistence of demersal fish assemblages between Cape Hatteras and Nova Scotia, Northwest Atlantic. J Northw Atl Fish Sci 14:29-46

Gotceitas V. Brown JA (1993) Substrate selection by juvenile Atlantic cod (Gadus morhua): effects of predation risk. Oecologia $93: 31-37$

Grimes CB, Able KW', Jones RS (1986) Tilefish, Lopholatilus chamaeleonticeps, habitat, behavior and community structure in Mid-Atlantic and southern New England waters. Envir Biol Fish 15:273-292

Langton RW, Auster PJ, Schneider DC (1995) A spatial and temporal perspective on research and management of groundfish in the northwest Atlantic. Rev Fish Sci 3 (in pressl

Malatesta RJ, Auster PJ, Carlin B (1992) Analysis of transect data for microhabitat correlations and faunal patchiness. Mar Ecol Prog Ser 87:189-195

Michalopoulos C (1990) A field study on the ecology and behavior of the winter skate (Raja ocellata) and little skate (Raja erinacea) off outer Cape Cod, Massachusetts. MSc thesis, Southeastern Massachusetts University, North Dartmouth

Murawski SA (1993) Climate change and marine fish distributions: forecasting from historical analogy. Trans Am Fish Soc 122:647-658

Overholtz WJ. Tyler AV (1985) Long-term responses of the demersal fish assemblages of Georges Bank. Fish Bull US $83.507-520$

Peters DS, Cross FA (1992) What is coastal fish habitat? In: Stroud RH (ed) Stemming the tide of coastal fish habitat loss. Marine Recreational Fisheries, Vol 14. National Coalition for Marine Conservation, Savannah, GA, p $17-22$

Phoel WC (1986) Community structure of demersal fishes on the inshore U.S. Atlantic continental shelf: Cape Ann, Massachusetts to Cape Fear, North Carolina. PhD

This article was presented by $K$. Sherman (Senior Editorial Advisori, Narragansett, Rhode Island, USA dissertatıon, College of William and Mary, Williamsburg, $\checkmark A$

Robins CR, Bailey RM, Bond CE, Brooker JR, Lachner EA, Lea RN, Scott WB (1991) Common and scientific names of fishes from the United States and Canada. Am Fish Soc Spec Publ 20

Sale PF (1991) The ecology of fishes on coral reefs. Academic Press, New York

Sissenwine MP (1984) Why do fish populatıons vary? In: May RM (ed) Exploitation of marne communities. SpringerVerlag, New York, p 59-94

Sissenwine MP, Cohen EB, Grosslein MD (1984) Structure of the Georges Bank ecosystem. Rapp P-v Réun Cons int Explor Mer 183:243-254

Sulak KJ (1982) A comparative ecological analysis of temperate and tropical demersal deep-sea fish faunas in the western North Atlantic. PhD dissertation, University of Miami, FL

Uzmann JR, Cooper RA, Theroux RB, Wigley RL (1978) Synoptic comparison of three sampling techniques for estimating abundance and distribution of selected megafauna: submersible vs camera sled vs otter trawl. Mar Fish Rev 39(12): 11-19

Valentine P, Uzmann JR, Cooper RA (1980) Geology and biology of Oceanographer Submarine Canyon, N.W. Atlantic. Mar Geol 38:283-312

Wahle RA (1992a) Substratum constraints on body size and the behavioral scope of shelter use in the American lobster. J exp mar Biol Ecol 159:59-75

Wahle RA (1992b) Body-size dependent anti-predator mechanisms of the American lobster. Oikos 65:52-60

Wahle RA, Steneck RS (1992) Habitat restrictions in early benthic life: experiments on habitat selection and in situ predation with the American lobster. J exp mar Biol Ecol 157:91-114

Walters CJ, Juanes F (1993) Recruitment limitation as a consequence of natural selection for use of restricted feeding habitats and predation risk taking by juvenile fishes. Can J Fish Aquat Sci 50:2058-2070

Wigley RL, Theroux RB (1970) Sea-bottom photographs and macrobenthos collections from the continental shelf off Massachusetts. US Fish Wildl Serv Spec Sci Rep Fish 613

Wigley RL, Theroux RB (1971) Association between postjuvenile red hake and sea scallops. Proc Natl Shellfish Ass $61: 86-87$

Wigley RL, Theroux RB (1981) Atlantic continental shelf and slope of the United States - Macrobenthic invertebrate fauna of the Middle Atlantic Bight region - Faunal composition and quantitative distribution. US Dept of the Interior, Geological Survey Professional Paper 529-N, Washington, DC

Manuscript first received: February 16, 1995

Revised version accepted: May 17, 1995 